\title{
Utjecaj pH želučanog sadržaja na čvrstoću kirurške rane
} želučane stijenke

\author{
Tara Kostanjšak*, Nika Brkljača Bottegaro, Andrea Martinović $i$ \\ Dražen Vnuk
}

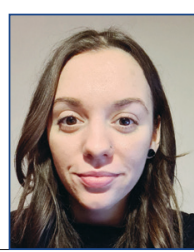

\section{Sažetak}

Promjene $\mathrm{pH}$ unutar lumena i u tkivu želuca mogu utjecati na svojstva materijala za šivanje rana. Pri kirurškim intervencijama izrazito niski pH mijenja fizikalna i biomehanička svojstva materijala za šivanje rana. U ovome radu uspoređivan je utjecaj $\mathrm{pH}$ na karakteristike dvaju materijala za šivanje rana korištenih prilikom izvođenja gastrotomije na ex vivo modelu svinje. Od četiri skupine u dvije skupine glikomer 631 i poliglikonat su bili izloženi pet dana klorovodičnoj kiselini (HCl-u), a u ostale dvije skupine ova dva materijala za šivanje rana nisu bili izloženi promjenama $\mathrm{pH}$. Ispitivanje je provedeno na svinjskim želucima na kojima je rez gastrotomije šivan dvoslojno glikomerom 631 i poliglikonatom. Nakon što su želuci bili ispunjeni tekućinom i prilikom popuštanja kirurške rane želučane stijenke, bilježene su vrijednosti tlaka, broj uboda potrebnih za šivanje prvog i drugog sloja kirurške rane, mjesto popuštanja šavova kirurške rane želučane stijenke i volumen tekućine potreban kako bi se razvio tlak potreban za popuštanje šavova. $\mathrm{Na}$ temelju dobivenih rezultata može se zaključiti kako $\mathrm{HCl}$ ima utjecaj na popuštanje šavova kirurške rane i promjenu njihovog svojstva. Poznavanjem utjecaja $\mathrm{HCl}-\mathrm{a}$ na monofilamentne šivaće materijale - glikomer 631 i poliglikonat, omogućena je lakša odluka pri odabiru materijala za šivanje rana prilikom zatvaranja kirurške rane želučane stijenke. Ovim istraživanjem dokazano je kako poliglikonat zadržava svoju postojanost dulje od glikomera 631 te kako je on pogodniji za zatvaranje želučane stijenke.

Ključne riječi: gastrotomija, $\mathrm{HCl}$, šavovi, kirurška rana, popuštanje šavova

\section{Uvod}

Najčešće izvođeni kirurški zahvati na želucu su: gastrotomija, parcijalna gastrektomija, gastroduodenostomija, gastrojejunostomija, piloromiotomija i piloroplastika. Operacije se želuca $u$ većini slučajeva izvode zbog prisutnosti

stranih tijela te zbog novotvorevina i nekroze prouzročene proširenjem i zavrnućem želuca u pasa. Od navedenih zahvata najčešće se izvodi gastrotomija. Gastrotomija je operacijski zahvat prilikom kojega se rezom kroz stijenku

Tara KOSTANJŠAK*, dr. med. vet., (dopisni autor, e-mail: tkostanjsak@vef.hr), dr. sc. Nika BRKLJAČA BOTTEGARO, dr. med. vet., izvanredna profesorica, dr. sc. Dražen VNUK, dr. med. vet., redoviti profesor, Veterinarski Fakultet Sveučilišta u Zagrebu, Hrvatska; Andrea MARTINOVIĆ, dr. med. vet., Specijalistička Veterinarska Ambulanta VetIva, Zagreb, Hrvatska 
želuca ulazi u njegov lumen kako bi se uklonilo najčešće strano tijelo iz njegova lumena (Radlinsky, 2018.). Strana tijela u želucu predstavljaju $16 \%$ do $50 \%$ pronađenih stranih tijela u probavnom sustavu. Najčešća strana tijela su: plastika, kosti, oštra strana tijela (kao na primjer udica), drvo i organski materijal. U nekim slučajevima nakon ingestije progutani se materijal mijenja pa može postati opstruktivno strano tijelo unutar želuca (Cornell, 2012.). Komplikacija zahvata izvedenog na želucu ovisi o čvrstoći i postojanosti materijala za šivanje rana te djelomična i potpuna dehiscencija rane i posljedični septični peritonitis koji može dovesti do smrti životinje. Čvrstoća i postojanost materijala za šivanje rana uvelike ovise o pH-u (Göpferich, 2006.).

Izbor materijala za šivanje rana ovisi o mnogobrojnim čimbenicima od kojih su najbitniji fizikalna i biomehanička svojstva materijala za šivanje rana, vrsta zahvata i tkiva na kojima se kirurški zahvat izvodi te subjektivni kriteriji poput lakoće manipuliranja materijalom i osobne sklonosti kirurga (Debus i sur., 1997.). Do razgradnje resorbirajućih šivaćih materijala najčešće dolazi zbog hidrolize alifatičnih esterskih veza. Dokazano je da hidroliza ovisi o temperaturi i $\mathrm{pH}$ tkiva te tekućine koja okružuje materijal za šivanje rana (Tomihata i sur., 2001.).

Glikomer 631 pripada skupini brzoresorbirajućih monofilamentnih materijala. Osobine su mu brza razgradnja, brz gubitak vlačne čvrstoće; kratko razdoblje podržavanja rane (gubitak $50 \%$ vučne čvrstoće u prvih 2-3 tjedna). Građen je od sintetičkog poliestera, glikomera 631, sastavljenog od glikolida (60\%), dioksanona (14\%) i trimetil karbonata (26\%). Poliglikonat pripada skupini spororesorbirajućih monofilamentnih materijala. Glikomer 631 građen je od poliglikonata, kopolimera glikolne kiseline i trimetil karbonata. Karakterizira ga spora razgradnja, dugo razdoblje podržavanja rane, postupan gubitak vlačne čvrstoće $\mathrm{i}$ resorpcija u predvidivom vremenu. Resorbirajući konci većinu vlačne čvrstoće gube unutar 60 dana od implantacije u tkivo. Načinjeni su od materijala koji se razgrađuju i resorbiraju pa se oočetna ili inicijalna vlačna čvrstoća ovog materijala za šivanje rana zbog toga smanjuje. Razgradnja se događa hidrolizom, fiziološkim procesom $\mathrm{u}$ predvidivom, poznatom razdoblju (Matičić i Vnuk, 2010.).

Cilj ovoga istraživanja bio je usporediti izdržljivost glikomera 631 i poliglikonata ovisno o $\mathrm{pH}$ te dokazati koliki je utjecaj želučanog sadržaja na njihovu postojanost. Dobiveni rezultati će odrediti koji je materijal pogodniji za šivanje rane gastrotomije.

\section{Materijali i metode}

\section{Svinjski želuci}

Istraživanje je provedeno na 16 svinjskih želudaca podrijetlom iz tovnih svinja, zaklanih $\mathrm{u}$ prehrambene svrhe $\mathrm{u}$ klaonici za proizvodnju i preradu mesa. Fakultetsko vijeće Veterinarskog fakulteta Sveučilišta u Zagrebu na prijedlog Povjerenstva za etiku $u$ veterinarstvu donijelo je odluku o prihvaćanju molbe kojim se traži suglasnost o etičkoj prihvatljivosti za istraživanje na uzorcima želuca (klasa: 640-01/19-17/18, urudžbeni broj: 251-61-44-19-02). Želuci su uzeti u vremenu do 3 sata nakon klanja, zajedno s početnim dijelom duodenuma i završnim dijelom jednjaka (duljine duodenuma i jednjaka oko $10 \mathrm{~cm}$ ) te su transportirani u hladnoj fiziološkoj otopini temperature od $4{ }^{\circ} \mathrm{C}$. Želuci su nasumično dodijeljeni svakoj skupini materijala za šivanje rana i to svakoj skupini po četiri želuca. $\mathrm{Na}$ ventralnom, dijelu svakog želuca napravljena je gastrotomija u dužini $5 \mathrm{~cm}$, između male i velike krivine paralelno s velikom krivinom želuca. 
Gastrotomija je šivana dvoslojno. U prvom sloju šivana je sluznica, dok su u drugom sloju šivani ostali slojevi želuca. Oba sloja šivana su jednostavnim produžnim šavom. Materijal za šivanje rana korišten za zatvaranje gastrotomije svakom želucu je dodijeljen slučajnim odabirom. Duljina rane podijeljena je u 3 dijela - početak, sredinu i kraj.

\section{Priprema materijala za šivanje rana korištenog za zatvaranje gastrotomije}

$\mathrm{Za}$ šivanje rane korišteni su poliglikonat (Maxon 3-0; Covidien, Irska) i glikomer 631 (Biosyn 3-0; Covidien, Irska) koji su ovisno o izloženosti $\mathrm{HCl}-u$ raspodijeljeni u 4 skupine. Prva skupina (P) sastojala se od poliglikonata koji nije bio izložen $\mathrm{HCl}-\mathrm{u}$, dok je druga skupina $(\mathrm{P}+\mathrm{HCl})$ bila sačinjena od poliglikonata koji je bio izložen $\mathrm{HCl}-\mathrm{u}$ pet dana. Glikomer 631 također je raspoređen u dvije skupine ovisno o svojoj izloženosti $\mathrm{HCl}-\mathrm{u}$, tako da je treća skupina $(\mathrm{G})$ formirana od glikomera 631 koji nije bio izložen $\mathrm{HCl}-\mathrm{u}$, a četvrta skupina $(\mathrm{G}+\mathrm{HCl})$ je bila formirana od glikomera 631 koji je HCl-u bio izložen, isto kao i druga skupina, 5 dana.

$\mathrm{Na}$ temelju anatomskih i histoloških karakteristika svinjskog želuca i njegove probave odlučeno je da će se upotrebljavati $\mathrm{HCl}$ čiji $\mathrm{pH}$ iznosi 3 . Vrijednost $\mathrm{pH}$ pripremljenog $\mathrm{HCl}-\mathrm{a}$ mjeren je pH-metrom (Mettler Toledo Seven Easy, Kina) koji mjeri $\mathrm{pH} \mathrm{s}$ točnošću \pm 0.01 .

\section{Ispitivanje intragastričnog tlaka}

Postojanost rane gastrotomije s materijalom za šivanje rana testirana je izdržljivošću korištenoga materijala prilikom povećanja intragastričnog tlaka. Tlak (mmHg) uzet kao tlak popuštanja rane gastrotomije zabilježen je u trenutku istjecanja tekućine između šavova kirurške rane želučane stijenke. Tlak je mjeren komoricom za invazivno mjerenje krvnoga tlaka (MeritMedical, DTX Plus, transducer s Critiflex integralnim „flush" uređajem i trosmjernim ventilom) te su njegove vrijednosti bile prikazane na anesteziološkom monitoru (Datex Ohmeda S5 Vital Signs Monitor, GE Healthcare, Kina). Kako bi se uočilo istjecanja tekućine prilikom popuštanja šavova gastrotomije, $\mathrm{u}$ fiziološku otopinu (Ecotainer, $\mathrm{NaCl}$ 0,9 \% 1000 mL, Braun, Njemačka) koji su bili izvor iste dodano je $2 \mathrm{~mL} \mathrm{1 \%}$ otopine metilenskog modrila (Methylene Blue - CAS 61-73-4, GramMol d.o.o., Hrvatska).

Prije punjenja želučane šupljine tekućinom završni dio jednjaka i početni dio duodenuma bili su zatvoreni tkivnom hvataljkom po Kocheru kako bi se izbjeglo istjecanje tekućine te kako bi se osiguralo odgovarajuće povećanje intragastričnog tlaka. Komorica za invazivno mjerenje krvnoga tlaka je preko intravenske kanile (Tikanila 2 G20 1,00 x $32 \mathrm{~mm}$, TIK d.o.o., Slovenija) povezana sa želučanom šupljinom. Fiziološka otopina je aplicirana u želučanu šupljinu pomoću igle (G20), infuzijskog sistema (Fresenius VL ST00, Fresenius Kabi, Francuska) i infuzijske pumpe (Fresenius Volumat MC Agilia Infusion Pump, Fresenius Kabi, Francuska). Brzina protoka tekućine iznosila je $1500 \mathrm{~mL} / \mathrm{h}$.

\section{Statistička analiza}

Vrijednosti tlaka zabilježene prilikom popuštanja kirurške rane želučane stijenke, broj uboda potrebnih za šivanje prvog i drugog sloja kirurške rane, mjesto popuštanja šavova kirurške rane želučane stijenke i volumen tekućine potreban kako bi se razvio tlak potreban za popuštanje šavova obrađeni su $u$ računalnom programu. Excell program korišten je za računanje prosječnog broja uboda potrebnog za zatvaranje reza gastrotomije, u oba sloja, i određivanje $\mathrm{u}$ kojem dijelu rane materijal za šivanje rana najčešće popušta. Pomoću SPSS Software-a (SPSS Inc., SAD) izračunate su minimalne i maksimalne vrijednosti 
volumena tekućine koji je bio prisutan $\mathrm{u}$ želučanoj šupljini prilikom popuštanja šavova želučane stijenke, srednja vrijednost i standardna devijacija za sve 4 skupine materijala za šivanje rana. Pomoću Pearsonovog koeficijenta korelacije određen je stupanj korelacije između ranije navedenih skupina, ovisno o izmjerenom intragastričnom tlaku i volumenu tekućine prisutnom unutar želuca $\mathrm{u}$ trenutku popuštanja šavova. Istim računalnim programom za dobivene vrijednosti intragastričnog tlaka izračunate su srednje vrijednosti, standardna devijacija. Vrijednost $P<0,05$ uzeta je kao statistički značajna. Računanjem korelacije dokazivalo se postoji li povezanost broja uboda igle i popuštanja šavova kirurške rane želučane stijenke. Naposlijetku, Hi-kvadrat testom ustvrđeno je postoje li razlike $\mathrm{u}$ postojanosti materijala za šivanje rana između poliglikonata i glikomera 631 koji su bili izloženi HCl-u te onih koji nisu bili izloženi HCl-u.

\section{Rezultati}

\section{Volumen tekućine}

Ako se gledaju sve 4 skupine, minimalna količina tekućine kojom je ispunjen želudac prije popuštanja šavova na mjestu kirurške rane iznosila je 2000 $\mathrm{mL}$, dok je maksimalna količina iznosila $5518 \mathrm{~mL}$. Srednja vrijednost volumena tekućine $\mathrm{u}$ želucima prilikom pucanja šavova bila je 3899,19 \pm 915,43 mL.
U tabeli 1. prikazane su vrijednosti količine tekućine kojom je ispunjen želudac prije popuštanja šavova $u$ svakoj pojedinoj skupini. Pearsonov koeficijent korelacije za volumena tekućine potreban kako bi došlo do popuštanja kirurške rane želučane stijenke, između skupina $\mathrm{P}$ i $\mathrm{P}+\mathrm{HCl}$ iznosi -0.740 , a $P$ vrijednost 0,260 dok između skupina G i G+HCl Pearsonov koeficijent iznosi 0,535 , a $P$ vrijednost 0,465 .

Dobiveni rezultati upućuju na postojanje srednje jake negativne povezanosti između volumena $u$ trenutku popuštanja šavova kirurške rane želučane stijenke između skupina $\mathrm{P}$ i $\mathrm{P}+\mathrm{HCl}$ koja nije statistički značajna.

Pearsonov koeficijent između skupina $\mathrm{G}$ i $\mathrm{G}+\mathrm{HCl}$, upućuju da postoji srednje jaki stupanj povezanosti između volumena u trenutku popuštanja šavova kirurške rane želučane stijenke između skupina $\mathrm{G}$ i $\mathrm{G}+\mathrm{HCl}$, a dobivena $P$ vrijednost upućuju da ona nije statistički značajna.

\section{Šivanje želučane stijenke i broj uboda iglom}

U prvom sloju rane bilo je potrebno 11,8 uboda iglom kako bi se zatvorila sluznica, a u drugom sloju je bilo potrebno 11,9 uboda iglom da bi se zatvorili ostali slojevi želuca. Obzirom na navedenu podjelu i broj uboda igle izračunat je postotak popuštanja šavova u pojedinim dijelovima rane.

Tabela 1. Vrijednosti volumena $(\mathrm{mL})$ tekućine prisutnog u želučanoj šupljini prilikom popuštanja šavova kirurške rane želučane stijenke za sve 4 skupine

\begin{tabular}{|l|c|c|c|c|c|}
\hline & N $^{1}$ & Min. $^{2}$ & Max. $^{3}$ & $\begin{array}{c}\text { Srednja } \\
\text { vrijednost }\end{array}$ & $\begin{array}{c}\text { Standardna } \\
\text { devijacija }\end{array}$ \\
\hline Skupina P & 4 & 3600 & 4528 & 3843,50 & 456,47 \\
\hline Skupina $\mathrm{P}+\mathrm{HCl}$ & 4 & 2000 & 5265 & 3517,50 & 1351,36 \\
\hline Skupina G & 4 & 4107 & 5518 & 4756,50 & 660,38 \\
\hline Skupina G+HCl & 4 & 2970 & 4266 & 3479,25 & 553,09 \\
\hline
\end{tabular}

${ }^{1} \mathrm{~N}$ - broj uzoraka; ${ }^{2}$ Min.- minimalna vrijednost; ${ }^{3}$ Max.- maksimalna vrijednost 
Tabela 2. Prosječni, minimalni i maksimalni broj uboda iglom napravljenih prilikom šivanja prvog i drugog sloja gastrotomije za sve skupine

\begin{tabular}{|l|c|c|}
\hline & 1. Sloj & 2. Sloj \\
\hline Prosječni broj uboda iglom & 11,8 & 11,9 \\
\hline Minimalni broj uboda iglom & 9 & 10 \\
\hline Maksimalni broj uboda iglom & 13 & 14 \\
\hline Standardna devijacija & 1,17 & 1,44 \\
\hline
\end{tabular}

Tabela 3. Korelacija između srednje vrijednosti tlaka izmjerenog prilikom popuštanja rane želučane stijenke i prosječnog broja uboda igle prilikom šivanja 1. i 2. sloja gastrotomije za sve 4 skupine

\begin{tabular}{|l|lr|}
\hline & $\begin{array}{l}\text { Prosječan tlak pri popuštanju šavova } \\
\text { želučane stijenke }\end{array}$ \\
\hline Broj uboda igle prilikom šivanja 1. sloja & $\begin{array}{l}\text { Pearsonov koeficijent } \\
\text { Pvrijednost }\end{array}$ & $-0,19$ \\
\hline Broj uboda igle prilikom šivanja 2. sloja & $\begin{array}{l}\text { Pearsonov koeficijent } \\
\text { Pvrijednost }\end{array}$ & 0,184 \\
\hline
\end{tabular}

Rezultati prikazani u tabelama 2. i 3 . dokazuju da nema statistički značajne povezanosti između popuštanja šavova kirurške rane želučane stijenke i broja uboda iglom u prvom sloju, ali da postoji statistički značajna povezanost između popuštanja šavova kirurške rane želučane stijenke i broja uboda iglom u drugom sloju.

Pearsonov koeficijent za skupine materijala za šivanje rana koji nije bio izložen HCl-u i vrijednosti prosječnog tlaka pri popuštanju šavova želučane stijenke iznosi $-0,122$, a $P$ vrijednost iznosi 0,77 što nam govori da između ovih vrijednosti postoji slaba negativna korelacija koja nije statistički značajna.

Pearsonov koeficijent za skupine šivaćeg materijala koji je bio izložen HCl-u i vrijednosti prosječnog tlaka pri popuštanju šavova želučane stijenke iznosi -0.173 , a $P$ vrijednost iznosi 0,68 što dokazuje da između ovih vrijednosti postoji slaba negativna korelacija koja nije statistički značajna.

\section{Mjesto popuštanja šavova}

Gledamo li sve skupine, bez obzira na njihovu izloženost $\mathrm{HCl}-\mathrm{u}, 75$ \% šavova popušta na početku kirurške rane, 18,75 $\%$ na sredini, dok svega $6,25 \%$ rana popušta na svom kraju (Slika 1.). Ako se promatraju skupine koje su bile izložene $\mathrm{HCl}-\mathrm{u}$ (skupine $\mathrm{P}+\mathrm{HCl}$ i $\mathrm{G}+\mathrm{HCl}$ ) rezultati se značajno ne razlikuju. Kod izloženosti HCl-u, 62,5 \% uzoraka popušta na početku rane, $12,5 \%$ uzoraka popušta na sredini rane dok $25 \%$ uzoraka popušta na kraju. U skupinama koje nisu bile izložene $\mathrm{HCl}-\mathrm{u}$ (skupine P i G), 87,5 \% uzoraka popustilo je na početku kirurške rane dok je svega 12,5 \% uzoraka popustilo na njezinom kraju.

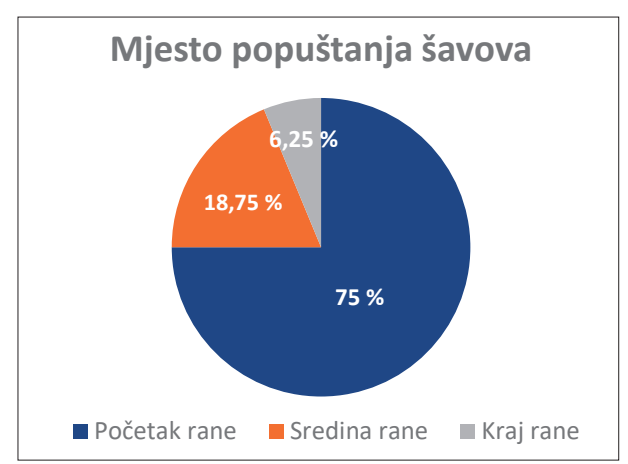

Slika 1. Grafički prikaz mjesta popuštanja šavova kirurške rane želučane stijenke u svih skupina 


\section{Intragastrični tlak}

Usporedbom rezultata prikazanih u Tablici 4 vidljivo je kako je tlak prilikom popuštanja šavova kirurške rane u prosjeku za $3 \mathrm{~mm} \mathrm{Hg}$ manji kod glikomera 631 koji nije bio izložen $\mathrm{HCl}-\mathrm{u}$ nego onaj koji se razvija unutar želuca prilikom popuštanja kirurške rane kod šivanja poliglikonatom koji nije bio izložen HCl-u. Kod skupina koje su bile izložene $\mathrm{HCl}-u$ vidljivo je kako je skupina u kojoj se koristio glikomer 631 došlo do popuštanja šavova na tlaku od 5,75 mmHg što je za $3 \mathrm{mmHg}$ niži tlak nego kod skupine u kojoj su kirurške rane zatvorene poliglikonatom. Izvođenjem Hi-kvadrat testa između skupina $\mathrm{P}+\mathrm{HCl}$ i $\mathrm{G}+\mathrm{HCl}$ dobivena je $P$ vrijednost od 0,07 koja upućuje da postoji razlika između glikomera 631 izloženog $\mathrm{HCl}-\mathrm{u}$ i poliglikonata izloženog $\mathrm{HCl}-\mathrm{u}$ koja nije statistički značajna, dok $P$ vrijednost izračunata za skupine P i G iznosi 0,38 što ukazuje na to da ne postoji značajna razlika između glikomera 631 i poliglikonata koji nisu bili izloženi HCl-u.

\section{Rasprava}

Postojanost materijala za šivanje rana, u ovom istraživanju, ispitivana je curenjem tekućine iz rane gastrotomije prilikom povećanja intragastričnog tlaka. Prilikom zatvaranja prvog sloja materijal za šivanje rana dolazi u neprekidni kontakt sa želučanim sadržajem niskog $\mathrm{pH}$ te je pod utjecajem promjena intragastričnog tlaka. Niski $\mathrm{pH}$ želučanog sadržaja u kontaktu s matrijalom za šivanjem rana mijenja njegova svojstva, a stupanj promjene svojstva prilikom kontakta sa želučanim sadržajem ovisi o vremenu izloženosti. Vrijeme izloženosti šivaćeg materijala $\mathrm{HCl}-\mathrm{u}, \mathrm{u}$ ovome istraživanju, određeno je na temelju spoznaje da želučane rane postižu maksimalnu čvrstoću 14. do 21 . dan nakon operacijskog zahvata, a da se vrhunac sinteze kolagena događa nakon svega 5 dana. U tom razdoblju, formacija kolagena povećava snagu tkiva, dok se vlačna čvrstoća korištenog materijala za šivanje rana postupno smanjuje (Kreszinger i sur., 2018.). U prvih 5 dana šivaći materijal samostalno podržava vučnu čvrstoću rane.

Klorovodična kiselina se u želučanu šupljinu izlučuje preko parijetalnih stanica gdje, zajedno s probavnim enzimima čini želučani sok čiji $\mathrm{pH}$ iznosi 3 . Osim što sudjeluje $u$ denaturaciji proteina smatra se da utječe na hidrolitičku razgradnju materijala za šivanje rana kojim se zatvara kirurška rana želučane stijenke (Tomihata i sur., 2001.).

Tlak popuštanja šavova kirurške rane uzimao se kao tlak prilikom kojeg je došlo do istjecanja tekućine između šavova kirurške rane želučane stijenke. Ovisno o sloju želučane stijenke koji se šiva, postoji povezanost između broja uboda iglom prilikom zatvaranja želučane stijenke i intragastričnog tlaka prilikom popuštanja šavova. Korelacija između broja uboda igle i tlaka prilikom kojega popuštaju šavovi želučane stijenke prisutna je prilikom šivanja drugog sloja, dok prilikom zatvaranja prvog sloja izostaje. Ovi rezultati nam upućuju da je prilikom zatvaranja želučane stijenke

Tabela 4. Srednje vrijednosti tlaka u mmHg (aritmetička sredina i standardna devijacija) prilikom popuštanja šavova kirurške rane želučane stijenke

\begin{tabular}{|l|c|c|c|c|}
\hline & Skupina P & $\begin{array}{c}\text { Skupina } \\
\mathrm{P}+\mathrm{HCl}\end{array}$ & Skupina G & $\begin{array}{c}\text { Skupina } \\
\mathbf{G}+\mathrm{HCl}\end{array}$ \\
\hline $\begin{array}{l}\text { Srednja vrijednost tlaka i } \\
\text { standardna devijacija }\end{array}$ & $11,25 \pm 0,95$ & $8,75 \pm 2,5$ & $8,25 \pm 3,59$ & $5,75 \pm 3,59$ \\
\hline
\end{tabular}


važno obratiti pozornost na šivanje drugoga sloja želučane stijenke. Osim što je dokazano kako je broj uboda igle napravljen u drugome sloju u povezanosti s tlakom prilikom popuštanja šavova uočilo se kako većina kirurških rana popušta na svome početku (između prvog i četvrtog šava) neovisno o tome je li materijal za šivanje rana bio izložen HCl-u ili nije. Mogući razlog najčešćeg popuštanja rane $\mathrm{u}$ njezinom početnom dijelu mogao bi biti u činjenici da prilikom razvijanja visokih intragastričnih tlakova dolazi do popuštanja čvora.

Razlika tlaka popuštanja između ispitivanog materijala za šivanje rana izloženog $\mathrm{HCl}-u$ i neizloženog $\mathrm{HCl}-\mathrm{u}$ iznosila je čak $3 \mathrm{mmHg}$. Na temelju dobivenih rezultata može se zaključiti kako $\mathrm{HCl}$ ima utjecaj na popuštanje šavova kirurške rane želučane stijenke. Dobivene razlike mogle bi se pripisati razlikama u kemijskom sastavu ispitivanog materijala za šivanje rana, međutim potrebno je napraviti dodatna istraživanja kako bi se to dokazalo.

Dobiveni rezultati podržavaju rezultate koje su dobili Tomihata i sur. (2001.) provedbom istraživanja o in vitro razgradnji materijala za šivanje rana. Sedam različitih šivaćih materijala uronjeno je $\mathrm{u} 4$ različite puferske otopine volumena $500 \mathrm{~mL}$ na temperaturi od 37 ${ }^{\circ} \mathrm{C}$. pH otopina iznosio je 1,0, 7,4, 8,5 i 10,5. Utjecaj puferskih otopina određivan je promjenama temperature tališta i pojavom morfoloških promjena na površini materijala za šivanje rana. Svojim istraživanjem dokazali su da glikomer 631 nije pogodan za šivanje tkiva $u$ okolini kiselog pH. Nakon izloženosti niskome $\mathrm{pH}, \mathrm{u}$ trajanju od 3 tjedna, glikomer 631 izgubio je $50 \%$ vlačne čvrstoće što ga čini nepogodnim za šivanje želučane stijenke. Istim istraživanjem dokazano je da i nakon tri tjedna izloženosti niskome $\mathrm{pH}$ poliglikonat nije uvelike promijenio svoja svojstva te kako je pogodan za zatvaranje rana želučane stijenke.
Rezultati ove studije, kojom su ispitani poliglikonat i glikomer 631, pokazuju kako $\mathrm{pH}$ otopine $\mathrm{u}$ koju je materijal za šivanje rana bio uronjen uvelike utječe na brzinu razgradnje ovih materijala, ovisno o njihovom sastavu.

Istraživanje koje su proveli Karabulut i sur. (2010.) u rezultatima se razlikuje od ranije navedenog istraživanja. Naime, $u$ istraživanju je ispitivana vlačna čvrstoća i izdržljivost materijala za šivanje rana $\mathrm{u} 9$ in vitro $\mathrm{i}$ in vivo uvjeta. Sedam uobičajeno korištenih materijala za šivanje rana (poliglikonat, poliglikolna kiselina, catgut, kirurška svila, polipropilen, poligliton i glikomer 631), testirani su u različitim kemijskim uvjetima i intraabdominalnim organima. Kroz rez gastrotomije veličine $3 \mathrm{~mm}$ na anteriornoj površini želuca štakora, 15 $\mathrm{cm}$ dug materijal za šivanje rana umetnut je u želudac. Rez gastrotomije zatvoren je poliprolenom 6-0, invertirajućim, pojedinačnim šavom $u$ jednom sloju. Nakon 5 dana izloženosti mjerena je vlačna čvrstoća izloženog materijala. Dokazano je kako su i glikomer 631 i poliglikonat pogodni za zatvaranje rana koje su izložene niskome $\mathrm{pH}$ te da materijal za šivanje rana, nakon što je bio izložen intragastričnim uvjetima, nije pretrpio gubitak vlačne čvrstoće. Prilikom provedbe istraživanja kemijska i fizikalna svojstva materijala za šivanje rana nisu uzeta u obzir.

Ograničenja ovog istraživanja bili su mali broj uzoraka po skupini, razlike u želucima na kojima je istraživanje provedeno (iako su želuci uzeti od svinja otprilike jednake mase moguće su razlike u debljini želučane stijenke i samoj veličini želuca zbog čega su moguće veće razlike $\mathrm{u}$ maksimalnom volumenu tekućine kojim je želudac ispunjen prije popuštanja šavova kirurške rane). Osim toga, nedostatak enzima koji se fiziološki nalaze u želučanom sadržaju mogao je imati utjecaja na razgradnju materijala za šivanje rana. 
Usprkos ranije navedenim ograničenjima, rezultati dobiveni ovim istraživanjem ukazuju da postoje razlike između glikomera 631 i poliglikonata nakon izloženosti HCl-u. Ovaj rad postavlja polazište budućim istraživanjima koja bi trebalo provesti ne bi li se $\mathrm{s}$ još većom sigurnošću ispitalo koji je od ova dva materijala za šivanje rana pogodniji za zatvaranje kirurške rane želučane stijenke. Preporuka za buduća istraživanja je da se provedu u kontroliranim uvjetima na većem broju uzoraka te da se obrati pozornost na ostale čimbenike koji imaju utjecaja na svojstva materijala za šivanje ranaa poput: želučanih enzima, temperature i promjena $\mathrm{pH}$ unutar želuca te kemijskih i fizikalnih svojstva samih šivaćih materijala.

\section{Zaključak}

Poliglikonat zadržava svoju postojanost dulje od glikomera 631 te je stoga pogodniji za zatvaranje želučane stijenke. Na temelju dobivenih rezultata može se zaključiti kako $\mathrm{HCl}$ ima utjecaj na popuštanje šavova kirurške rane želučane stijenke. Intragastrični tlak pri popuštanju gastrotomije iznosio je najviše u skupini šivanoj poliglikonatom neizloženim $\mathrm{HCl}$ om, dok je najmanji intragastrični tlak pri popuštanju gastrotomije zabilježen u skupini šivanoj glikomerom 631 izloženom HCl-u. Usprkos znanju i stručnosti u pojedinim slučajevima dolazi do popuštanja materijala za šivanje rana prilikom zatvaranja kirurške rane, zbog čega se mora obratiti pozornost na njihovu postojanost $u$ različitim medijima u kojima se primjenjuju. U ovom istraživanju poliglikonat je povoljniji materijal za šivanje rana od glikomera 631 za zatvaranje kirurške rane želučane stijenke.

\section{Literatura}

1. CORNELL, K. (2012): Stomach. In: Veterinary surgery, small animal: Volume two. (Tobias K. M., S. A. Johnston, eds.), Elsevier Saunders. St. Louis, Missouri, (1700-1730)

2. DEBUS, E. S., D. GEIGER, M. SAILER, J. EDERER and A. THIEDE (1997): Physical, biological and handling characteristics of surgical suture material: a comparison of four different multifilament absorbable sutures. Eur. Surg. Res. 29, 52-61.

3. GÖPFERICH, A. (2006): Mechanisms of polymer degradation and erosion. In: The Biomaterials: Silver Jubilee Compendium, (Williams, D. F., ed.). Elsevier Science. St. Louis, Missouri, (119).

4. KARABULUT, R., K. SONMEZ, Z. TURKYILMAZ, B. BAGBANCI, A. C. BASAKLAR and N. KALE (2010): An in vitro and in vivo evaluation of tensile strength an durability of seven suture materials in various $\mathrm{pH}$ an different conditions: an experimental study in rats. Indian J. Surg. 72, 386-390.

5. KRESZINGER, M., B. TOHOLJ, A. AČANSKI, S. BALOŠ, M. CINCOVIĆ, M. PEĆIN, M. LIPAR and O. SMOLEC (2018): Tensile strength retention of resorptive suture materials applied in the stomach wall - an in vitro study. Vet. arhiv 88, 235-243.

6. MATIČIĆ, D. i D. VNUK (2009): Kirurški šivaći materijal. U: Veterinarska kirurgija i anesteziologija. (Matičić D., D. Vnuk, ur.), Medicinska Naklada, Zagreb, (67-85).

7. RADLINSKY, M. G. (2018): Surgery of the Digestive System. In: Small animal surgery, $5^{\text {th }}$ Edition. (Fossum, T. W., J. Cho, C. W. Dewey, K. Hayashi, J. L. Huntingford, C. M. MacPhail, J. E. Quandt, M. G. Radlinsky, K. S. Schutz, M. D. Willard, A. Yu-Speight, eds.), Elsevier Saunders, St. Louis, Missouri, (398, 401, 415).

8. TOMIHATA, K., M. SUZUKI and Y. IKADA (2001): The $\mathrm{pH}$ dependence of monofilament sutures on hydrolytic degradation. J. Biomed. Mater. Res. 58, 511-518. 


\section{Influence of gastric $\mathrm{pH}$ on the strength of sutured surgical wounds of the gastric wall}

Tara KOSTANJŠAK, DVM, Nika BRKLJAČA BOTTEGARO, DVM, PhD, Associate Professor, Dražen VNUK, DVM, PhD, Full Professor, Faculty of Veterinary Medicine University of Zagreb, Croatia; Andrea MARTINOVIĆ, DVM, Specijalist Veterinary Clinic VetIva, Zagreb, Croatia

Changes in $\mathrm{pH}$ within tissue, such as the extremely low $\mathrm{pH}$ in the stomach, can alter the physical and biomechanical properties of suture materials. In this paper, the influence of $\mathrm{pH}$ on the characteristics of two suturing materials used in gastrotomy on an ex vivo model of a pig was compared. In two experimental groups, glycomer 631 and polyglyconate were exposed to hydrochloric acid $(\mathrm{HCl})$ for five days, while in the two control groups, the same two suture materials were not exposed to $\mathrm{pH}$ changes. The study was performed on pig stomachs on which the gastrotomy incision was sutured in two layers with glycomer 631 or polyglyconate. After the stomachs were filled with a certain amount of fluid, the pressure values at the dehiscence of the surgical wound of the gastric wall, the number of stitches required to suture the first and second layers of the surgical wound, the location of dehiscence of the sutures of the surgical wound of the gastric wall, and the volume of fluid required to develop dehiscence of sutures were recorded and statistically analysed. Based on the obtained results, it can be concluded that $\mathrm{HCl}$ has an effect on loosening surgical wound sutures and in changing their properties. Knowing the influence of $\mathrm{HCl}$ on monofilament sutures - glycomer 631 and polyglyconate, allows for better decision-making when choosing a suture material to close surgical wounds of the stomach wall. This study showed that polyglyconate retained its stability longer than glycomer 631 and is therefore more suitable for closing the stomach wall.

Key words: gastrotomy; $\mathrm{HCl}$; sutures; surgical wound; suture dehiscence 